\title{
FAS wt Allele
}

National Cancer Institute

\section{Source}

National Cancer Institute. FAS wt Allele. NCI Thesaurus. Code C51383.

Human FAS wild-type allele is located in the vicinity of 10q24.1 and is approximately $26 \mathrm{~kb}$ in length. This allele, which encodes tumor necrosis factor receptor superfamily member 6 protein, plays a role in the initiation of the caspase processing cascade that leads to programmed cell death. Mutations in the gene are related to autoimmune lymphoproliferative syndrome type 1A, burn scar-related squamous cell carcinoma and lung cancer susceptibility. 